\title{
AN INVESTIGATION OF ARCHAEOLOGICAL REMAINS AT LAMREH SITE, ACEH, INDONESIA AND THEIR CONTEXT WITHIN THE LAMURI KINGDOM
}

\author{
Amir Husni* \\ Centre for Global Archaeological Research, Universiti Sains Malaysia, \\ 11800 USM Pulau Pinang, Malaysia \\ E-mail: amirhusni92@gmail.com \\ Saryulis $^{* *}$ \\ Centre for Global Archaeological Research, Universiti Sains Malaysia, \\ 11800 USM Pulau Pinang, Malaysia \\ E-mail: saryulis.s.pd@gmail.com

\section{Husaini Ibrahim ${ }^{* * *}$} \\ Department of History, Faculty of Education, Universitas Syiah Kuala, \\ 23111 Banda Aceh, Indonesia \\ E-mail: husibram@gmail.com

\section{Mokhtar Saidin ${ }^{* * * *}$} \\ Centre for Global Archaeological Research, Universiti Sains Malaysia, \\ 11800 USM Pulau Pinang, Malaysia \\ E-mail:mmokh@usm.my
}

Published online: 15 July 2019

To cite this article: Husni, A. et al. 2019. An investigation of archaeological remains at Lamreh site, Aceh, Indonesia and their context within the Lamuri Kingdom. International Journal of Asia Pacific Studies 15 (2): 59-88, https://doi.org/10.21315/ ijaps2019.15.2.3

To link to this article: https://doi.org/10.21315/ijaps2019.15.2.3

\footnotetext{
ABSTRACT

This study contributes to provide a deeper understanding of the artefacts found at Lamreh site and their context within the history of Lamuri Kingdom. To this end, a comprehensive investigation was performed over three weeks at Lamreh, where several archaeological findings had been recovered which consisted of plak- 
pling gravestones, imported ceramics, glassware and Chinese coins. The plak-pling gravestones were dated back to the 15th century CE, including one with the inscription of Sultan Muhammad bin Alauddin who was possibly one of the royal officials of the Lamuri Kingdom. The shapes and motifs of the plak-pling gravestones displayed a strong influence of the pre-Islamic Hindu-Buddhist culture. In addition, other interesting findings were imported ceramics, despite their fragmented condition, are both interesting, help with dating the site, and provide a better understanding of economic, social networks and value chains. Morphological, technological and contextual analyses, as well as relative dating, were used to reconstruct the shapes, types, origin and ages of the ceramics, as well as to identify them based on classes of export ceramics from China and Southeast Asia from 14th until the 15th century $C E$. Additionally, the glassware had been identified as a Chinese type dating back to at least the 13th to 14th century CE. Therefore, these pieces of evidence suggested that Lamreh was an important market for the ceramics trade in Southeast Asia for 300 years. These and other findings had proven that Lamreh was an urban trading centre in the Lamuri Kingdom which had strong connections in both the South China Sea and the Indian Ocean around a thousand years ago. The artefacts unearthed there had also provided evidence of a religious, cultural and commercial relationship between Lamuri and the outside world from approximately $1200 \mathrm{CE}$.

Keywords: Archaeology, Lamuri Kingdom, plak-pling gravestones, trade ceramics, Lamreh site

\section{INTRODUCTION}

The province of Aceh in Indonesia is famous for the Islamic archaeological remains. One of the most interesting areas in Aceh is the Lamreh site, Aceh Besar. This region is located on the western tip of the island of Sumatra and faces the Straits of Malacca, Bay of Bengal and Indian Ocean.

Maritime trade was the main reason Islam first entered the Indonesian archipelago. At the beginning of the seventh century CE, Arabian Muslim traders were the most dominant group of voyagers in the oceans of Southeast Asia (Chaudhuri 1985; Risso 2018). At the time, this area served as a place of transit before the traders continued their journey onwards either to China or back home to the Middle East (Hall 2010). In the seventh century, Sriwijaya was the largest transit port in the Straits of Malacca, managing to control the exchange of goods between east and west (Chuan and Cleary 2005). Several centuries later, the power of Sriwijaya had weakened to the extent that new territories emerged and provided various facilities desired by international traders (Gipouloux 2011). Among the emerging ports of the 11th century were 
Kota Cina on the east coast and Barus on the west coast of Sumatra (McKinnon 1977). Both these areas became global ports in which traders were able to carry out their economic activities. This is based on the archaeological finds recovered from both regions, such as the 12th century CE Chinese ceramics and 12th century CE glass from the Middle East (Perret and Surachman 2015).

The other area on the island of Sumatra which also came to prominence in the first century CE of the millennium was Lamuri. News about Lamuri's emergence was delivered by Ibn Khurdadbih in his ninth century CE record (McKinnon 1988). From the 800s, Lamuri started to be frequented by foreign traders. Some words which resembled the word Lamuri also appeared in the records of other foreign traders until the 15th century CE (Cowan 1933). Based on these records, it was understood that Lamuri emerged as the most recent of the new port cities from the onset of the tenth century CE. These pieces of information served as the references to determine Lamuri's location.

A survey conducted in significant locations in Aceh revealed the resemblance of the word Lamuri to the word Lamreh. It is the name of a village in Aceh Besar located 50 kilometres north of the provincial capital, Banda Aceh. It is located on the coast facing the Straits of Malacca, Bay of Bengal and the Indian Ocean. The results of a preliminary archaeological survey found several types of archaeological remains in this area such as gravestones, ceramics and pottery. Interestingly, there are still a lot of gravestones, ceramics and pottery that can be found on the surface of this region. The vast quantity of archaeological remains in this region, thus, represents the primary reason for selecting this region as the research area.

\section{RESEARCH METHODS}

This study was designed to identify the archaeological remains at the Lamreh site as well as to determine their relation to the site and features, better discern the nature of the site (physically, socially and economically), and better understand trade and exchange networks, culture influences and sitespecific activities. To achieve the objectives, various archaeological research methods were used. Firstly, a three weeks survey on site identified several kinds of artefacts and their relative distributions, densities and conditions. A stratified-random sampling technique was applied to record the gravestones and ceramics as the main sources of chronological data. This technique was chosen because it is very suitable for the topography, size and condition of the site. It is hilly and covered with dense vegetation rendering it difficult to 
access. All gravestones were recorded in detail including their shapes, motifs and associations. All the ceramic fragments larger than two centimetres were collected for analysis. Glassware and coins were also identified and collected for further analysis. Secondly, detailed literature and library studies were also conducted to obtain ancient records and archives relating to Lamuri as supporting data.

Lastly, various assemblage analyses were conducted using several methods. The first consisted of basic morphological analyses to identify the artifacts' shapes and create a typology. Secondly, technological analyses were performed to ascertain the technology used to create the artifacts. Lastly, contextual analysis was used to determine the relationship between the artifacts and the site itself. Furthermore, relative dating was used to determine artifact and site ages. Dates for gravestones were obtained from inscriptions carved on tombstone panels. Some tombstones that did not have a temporal inscription were compared with similar tombstone morphologies and styles containing inscribed dates. Other artifacts such as ceramics were compared to similar types of ceramics found from archaeological research across Southeast and East Asia (China in particular regarding the latter, as Song-Yuan Dynasty and later ceramics are highly represented in the region).

\section{PREVIOUS RESEARCH ON ARCHAEOLOGICAL REMAINS AT LAMREH SITE}

The word Lamuri often appeared in historical references especially in relation to ancient maritime trades in the oceans of Southeast Asia. Lamuri was frequently mentioned as a place of transit on the island of Sumatra (Adhyatman 1990). However, all the related writings on Lamuri were very brief and were summarised through a historical approach. McKinnon (1988) was the first person who attempted to view the significance of Lamuri through an archaeological study. He conducted a survey in the coastal area of Ujong Pancu, located approximately 60 kilometres south of the Lamreh site. During this survey, he found several Chinese ceramic fragments from the 13th and 14th centuries CE produced by the Song and Yuan dynasties of China. He eventually concluded that the centre of the kingdom was located in presentday Ujong Pancu, west coast of Banda Aceh.

This was later rebutted by Suwedi Montana (Montana 1997) who did an archaeological study in the province of Aceh in September 1995 to investigate the Lamuri Kingdom by using the Aceh gravestone approach. The results of his published research showed that five gravestones were present at the site 
of Lamreh, which he claimed to be the centre of Lamuri Kingdom. However, the total number of gravestones at Lamreh was actually more than what Suwedi Montana had previously reported, and this will be discussed later. Before going any further to describe the existence of the Lamuri Kingdom, we need to look back at the records written by foreign explorers about this kingdom. Such information is useful to construct a new hypothesis on the rise and development of the kingdom.

\section{HISTORICAL RECORDS ON LAMURI}

The rise of Islam in Arabia in the seventh century CE had a major impact on the maritime trade map in the waters of Southeast Asia, especially along the Straits of Malacca (Chuan and Cleary 2005; Hall 2010). From this time on, the number of Muslim Middle East traders in international voyages began to increase. They were the most dominant group of people to trade with Southeast Asian markets as well as spread Islamic faith-resulting in increasing and strong economic, cultural and ideological networks. Apart from traders and $d a{ }^{\prime} i$ (someone who invites people to Islam), there were also Muslim geographers within the group who actively wrote about Southeast Asian ports, kingdoms, geography and people (Risso 2018). One of the areas visited by these Arab traders was Lamuri (Brebbia and Boquera 2016).

The word Lamuri first appeared in the Arabic encyclopedia in the ninth century CE. Ibn Khurdadbih wrote, "Beyond Serandib is the isle of $\operatorname{Ram}(n) i$, where the rhinoceros can be seen... This island produces bamboo and brazilwood, the roots of which are an antidote for deadly poisons... This country produces tall camphor trees" (Meri 2005). At the same time, in an ancient Arabic encyclopedia called Akhbar al-Sin wa'l Hind, Lamuri was also mentioned to lie between two seas called Harkand and Salahit (Wolters 1967). Historians believed that Harkand referred to the Bay of Bengal, while Salahit came from the Malay word for strait, thus, referring to the Straits of Malacca. These sources indicated that Lamuri was a rich region located on the western tip of the island of Sumatra (Meri 2018).

There were also other notes written about Lamuri before the 11th century CE by international geographers. All of them spoke about the wealth of Lamuri. Abu Zaid Hasan (916 CE) wrote that Lamuri had a camphor garden, brazilwood and other plants. He also mentioned that Lamuri was under the Kingdom of Sriwijaya (Maharaja Zabaj) which was 800 farsakh in area (Tibbetts 2002). Farsakh is a Persian unit of distance equivalent to approximately 10 kilometres or 6.21 miles. 
According to the al-Masudi's record (943 CE), an Arabian geographer who visited Lamuri 27 years after the arrival of Abu Zaid Hasan, Lamuri was continuously visited by foreigners. He noted that Lamuri was a region ruled by a king and was rich in gold mines as well as forest product especially highquality camphor (Tibbetts 2002).

The most popular Arab encyclopedia referring to Lamuri was Akhbar al-sin wa'l Hind (1000 CE). One of the authors was Muhammad ibn Babishad. He noted that Lamuri was located next to Fansur, a coastal city in Sumatra Island. He also listed the unique animals of this region such as Zarafa known as the two-horned Sumatran rhinoceros and large ants (Tibbetts 2002).

An ancient toponym that had a strong resemblance to the word Lamuri was found in the Tanjore inscription from Tamil, South India. In the inscription, the name Illamuridesam was written together with other regions as an area that was attacked by Rajendra Cola in 1025 CE (Wheatley 1959).

However, the records do not end there. Since the 12th century CE, Chinese sources began to mention Lamuri's name. Chou Ch'u-fei (1178 CE) was the earliest Chinese trader who gave an overview of global activities at Lamuri. He quoted that Lamuri (Lan-li) was a producer of white saplings, elephants as well as rattan, and served as a transit point for ships from Canton (Guandong) to wait for the monsoon winds to end before continuing their journey to Sri Lanka and India (Suryadinata 2005).

In the 13th century CE, Marco Polo's records mentioned Lamuri as an Islamic state along with other ancient toponyms in Sumatra. He said that previously Lamuri sent tributes to the Yuan Dynasty in 1284 and $1286 \mathrm{CE}$, and this region was rich with valuable forest product such as timber and camphor (Reid 1995; Yule 2018).

Records on Lamuri as a global trading centre in early 14th century CE had also appeared in Persian records. Ibn Rashiddun in $1310 \mathrm{CE}$ noted that many merchants from different countries came to Lamuri (Lamori) to seek for camphor, gold and lign-aloes (Yule 2018).

The most comprehensive note from China on Lamuri was written by Wang Ta-yuan, a traveller who visited Southeast Asia in the 14th century CE. In $1349 \mathrm{CE}$, he noticed that Lamuri (Nan-wu-li) was an important trading place (Yule 2018). The area, he described, was surrounded by bumpy hills and faced directly to the sea. All the people in this region lived on the hills and each family had their own home. The climate in the Lamuri region was very hot, the land was barren, and their quality products were bird's nests, tortoise shells and perfumes with a stronger scent than those from other areas. The products traded with China, according to Wang Ta-yuan, were gold, silver, 
iron goods, camphor, blue and white porcelain ceramics as well as some other items (Suryadinata 2005; Yule 2018).

A Chinese diplomat of Ming Dynasty, Zheng He visited Lamuri in the 15th century CE had provided comprehensive demography of Lamuri. Ma Huan, Zheng He's clerk, referred to Nan-po-li (Lamuri) as the region visited by them. He noted that Lamuri was situated beside the sea and had a population of more than one thousand families. All the people in this region were very good Muslims (Sen 2009; Suryadinata 2005). He also noticed an island located in some nautical offshore to the northwest of Lamuri country. Another Chinese historical record called this island as "Hat Island" which was rich in lign-aloes. The island, as recorded by Ma Huan, was part of Lamuri country. There was a tall mountain which was usually used by sailors as a natural landmark while travelling the ocean. The island was believed to be Pulau Weh or Sabang Island, an island located directly northwest of Banda Aceh (Suryadinata 2005).

A final note about Lamuri was written by Tomé Pires, a Portuguese apothecary who visited Southeast Asia in the early 16th century CE. He wrote that Aceh (Achin) was the first country located at the junction of Sumatra Island and Lamuri (Lambri) was located on the right side of Achin country (Cortesão 2017).

From the above-mentioned notes, it can be concluded that Lamuri was formed around the ninth century CE. The region was visited by merchants from various countries, but particularly from the Middle East and China. Lamuri went on to become an important trade centre in Southeast Asia in the 13th century CE and by this time the local people had heartily embraced Islam.

\section{ARCHAEOLOGICAL REMAINS FROM THE LAMREH SITE}

Based on the results from the survey at the Lamreh site, various archaeological remains were found (Figure 1). These remains were very important to reconstruct Aceh's history, especially over the last thousand years. The archaeological remains at the Lamreh site were essentially divided into the following categories: gravestones, imported ceramics, glassware and Chinese coins. 

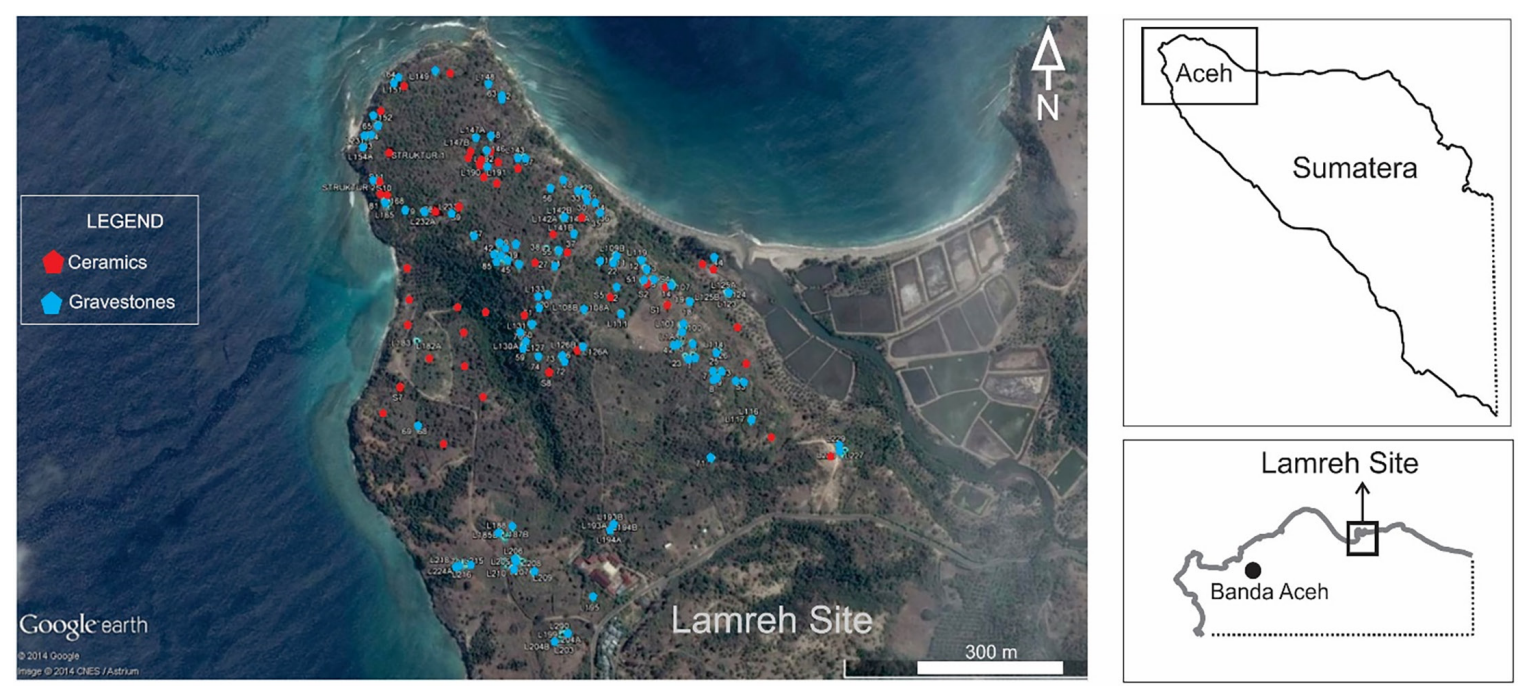

Figure 1: Site location and artifact distribution at Lamreh site, Aceh, Indonesia.

\section{Gravestones}

Gravestones were the most common artifacts found at the Lamreh site. In the Nusantara region, gravestones or batu nisan are, and were, used to mark Muslim graves (Perret et al. 1999). Nonetheless, the shapes of the Aceh Stones discovered at the Lamreh site were unique and their appearances were quite significant. These gravestones are known as plak-pling type by the local community and they were found in significant numbers at the Lamreh site. This area contained 200 gravestones with numerous variations of decoration and size (Figure 2). The plak-pling gravestones had pillar-shaped bodies with pyramid-shaped tops. They were somewhat phallic and resembled menhirs (Awang 2012). The tops of the gravestones usually consisted of several levels that reflected the influence of Hindu-Buddhist culture as shown in Figure 2(b). The ornamental motifs carved on these gravestones were very distinct and different from those on other types of gravestones. The most common decoration carved on plak-pling gravestones was a tendril along with a clear flower motif as shown in Figure 2(c). The type of flower carved on these gravestones was identified as a lotus petal, frequently found on Chinese and Vietnamese under-glazed blue ceramics of the 14 th to 15 th century CE, similar to the example in Figure 5.

Interestingly, Arabic calligraphy was engraved on the body sections of the plak-pling gravestones. The information conveyed consisted of verses from the Qur'an explaining the concept tawheed, as well as poetry and a biography of the gravestone's owner. Among the Qur'anic verse that had been identified was Surah ar-Rahman verse 26 which proclaimed that all men will 
die and only God will be eternal. Meanwhile, the Sufi poetry inscribed on the gravestones cautioned that all human beings will die. One example of this was "death is the door and all men will enter it." However, the gravestones on which this Sufi poetry and Qur'anic verses were carved did not mention a year. Generally, the plak-pling tombstones featuring Sufi poetry and Qur'anic verses are made of yellowish sandstone. Some of the tombstones were broken and some of the decorations had worn off.

The most important discovery was the Sultan's gravestone, as identified by its inscriptions. Out of all the plak-pling gravestones at the Lamreh site, only a single gravestone seemingly belonged to a Sultan. The written inscription on this gravestone was "this is the grave of Sultan Muhammad bin Alauddin who died on Monday, 20 Zulqaidah year 834 Hijriah." If converted to Gregorian years, this would mean that Sultan Muhammad Alauddin died in $1431 \mathrm{CE}$. This gravestone was made of granite and was found with half of its body embedded into the ground, shown in Figure 2(a).

One gravestone bore the written inscription, "This is the grave of the weak servant Malik Syamsuddin who died on Saturday, 30 Ramadan 822 H." If converted to the Gregorian calendar, Malik Syamsuddin died in 1419 CE. Another discovered gravestone belonging to a royal official was that of Malik Zainal Abidin. Unfortunately, Malik Zainal Abidin's headstone was broken, especially at the top, and some parts of its inscription were destroyed, thus obscuring the year of his death. However, based on the tombstone's shape and decorations, it was suspected that Malik Zainal Abidin also died around the same time as Malik Syamsuddin at the beginning of the 15th century CE.

Another important discovery was a gravestone inscribed with the name Abdurrahim. On the gravestone, the epitaph also described that he was a weak servant and afraid of the Creator. Some verses of the Qur'an were also inscribed on Abdurrahim's headstone, as in Figure 2(b). This gravestone was made of sandstone and stood one metre tall, higher than most other plak-pling gravestones. 


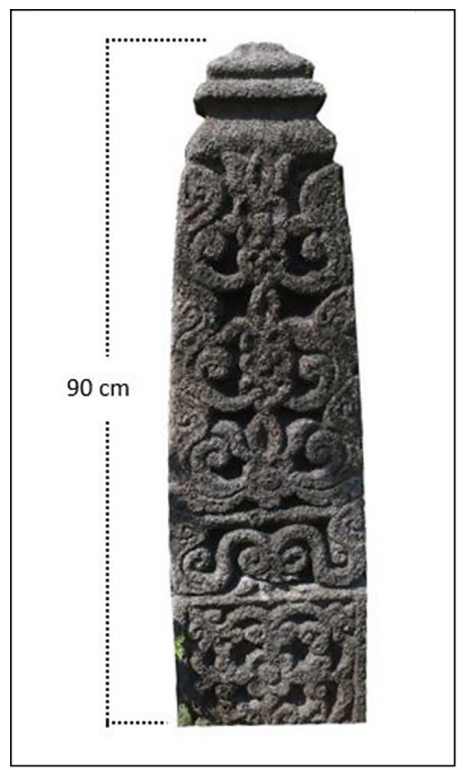

a

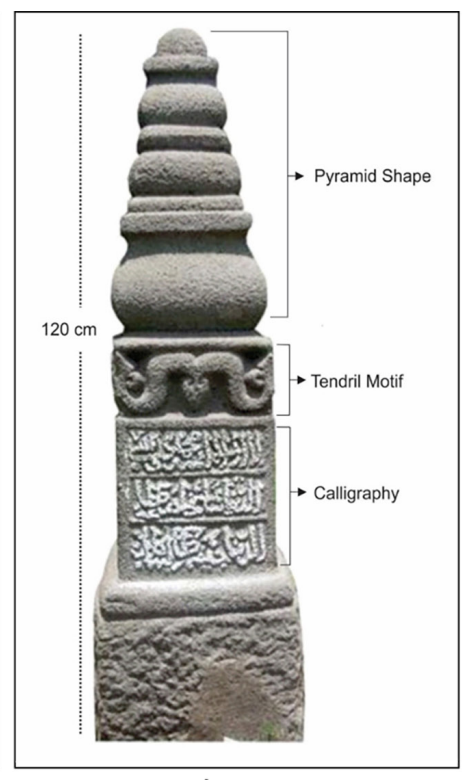

b

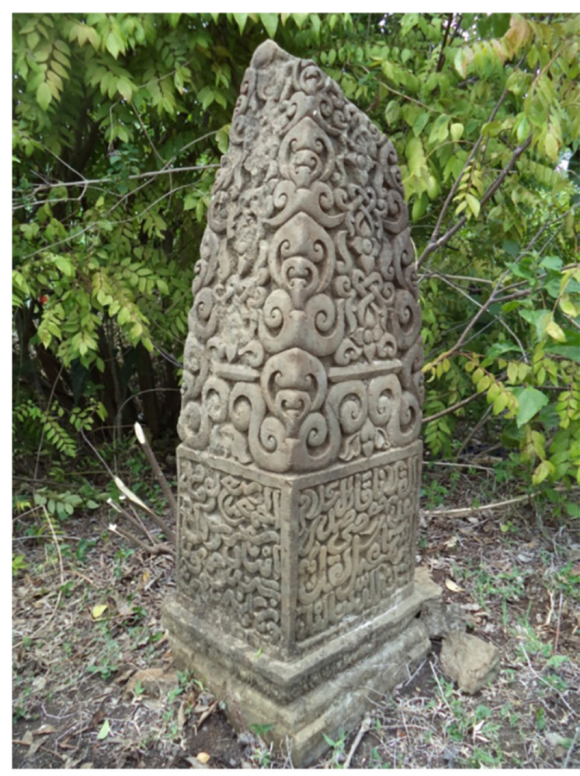

C

Figure 2: Plak-pling gravestones at Lamreh site, showing (a) the gravestone of Sultan Muhammad bin Alauddin (15th CE), (b) gravestones of Abdurrahim, and (c) the plak-pling gravestones with calligraphy and a distinctive motif.

\section{Imported Ceramics}

With references to previous research, a ceramic classification format was created by Harrisson (1959) based on their research in Borneo. Edwards McKinnon (1984) subsequently used the same classification format for his research in Kota Cina. According to this format, any discovered ceramics are classified by type. The classification of the ceramics found at the Lamreh site was largely in line with the classification format created by Harrison and Edwards McKinnon. However, the ceramic classification format was slightly modified since the ceramics at Lamreh were generally found in fragments. Therefore, all the ceramics discovered were divided into three types, namely rim sherds, body sherds and base sherds. It was thought that this method would enable the reconstruction of the ceramics' original form. The types of ceramics found at the Lamreh site included celadon, Qingbai, blue and white porcelain, coarse stoneware, Thai ware, Burmese ware as well as Vietnamese ware. Other interesting findings were unglazed wares, glassware and Chinese coins.

\section{Celadon}

The term celadon refers to green-glazed ware. They have variant glaze colours including bluish-green, greyish-green, yellowish-green, pale green and olive 
green. Some of them feature transparent glaze, heavy crackled glaze or smooth glaze. Celadon was originated from China with the notable kiln at Longquan city, Zhejiang, South China. This ceramic was exported in huge numbers since the 12th century CE as one of China's official export commodities (Wood 1999; Valenstein 1988).

Celadon was the most common type of ceramic found at the Lamreh site, accounting for half of the total ceramic fragments discovered (Figure 10). Numerous fragments of celadon ware were collected during fieldwork and were subsequently divided into two types. The first of these- the rim sherds - vary greatly. There are flattened rims, flattened rims with raised edges, straight rims, everted rims and folded rims - all in different sizes. The smallest size of rim sherds was two centimetres while the largest size was eight centimetres in diameter. However, the common size of rim sherds was four to five centimetres in diameter. The glaze colours were plum green, faded green, green glaze, bluish-green, pale green and opaque green. Half of them had heavily crackled glaze while the rest were without the crackled glaze. They had a thick glaze applied on an off-white or greyish-white fabric. The familiar exterior motifs were surrounded by incised horizontal lines and incised floral designs. Other familiar motifs are moulded lotus petals and incised vertical flutings. The interior rim motifs, meanwhile, featured incised horizontal flutings and floral designs.

The second type of celadon fragments discovered were base sherds which were divided into two categories - flat base and ring foot. There was not much variation in the flat base type. A thin glaze of pale green was applied on grey fabric. The interior of the recessed base was unglazed and brick-red in colour. As for the ring foot type, there was quite a lot of variety. There were examples of ring foot bases sherds which were normal, had a trimmed corner on the interior or had a trimmed corner on the exterior. They featured different glaze colours such as green, bluish-green, pale green, olive green and yellowish-green. Some of them had heavily crackled glaze while others were quite smooth. Most of them had thick celadon glaze applied on an offwhite fabric or greyish fabric. In some of them, the glaze covered the entire ceramic body, while in others the lower exterior to the base and biscuit ring in the centre was unglazed. Furthermore, a few sherds had under-glaze incised decorations with medallion motifs on the interior and incised vertical lines on the exterior. The general size of base fragments of celadon ware from Lamreh site was seven to eight centimetres while the largest sizes of base fragments were above 12 centimetres; however, the number was very small. 
Morphological analysis revealed that the shapes of celadon ware from the Lamreh site were those of bowls, dishes, jars, covered boxes and other household wares (Figure 3). Some of them were of great quality, glossy, thin and light white. The familiar interior motifs of celadon ware from the Lamreh site were lotus petals, moulded floral decorations, incised peony flowers and a fish among waves, as well as stippled floral decorations and moulded decorations of flower sprays.
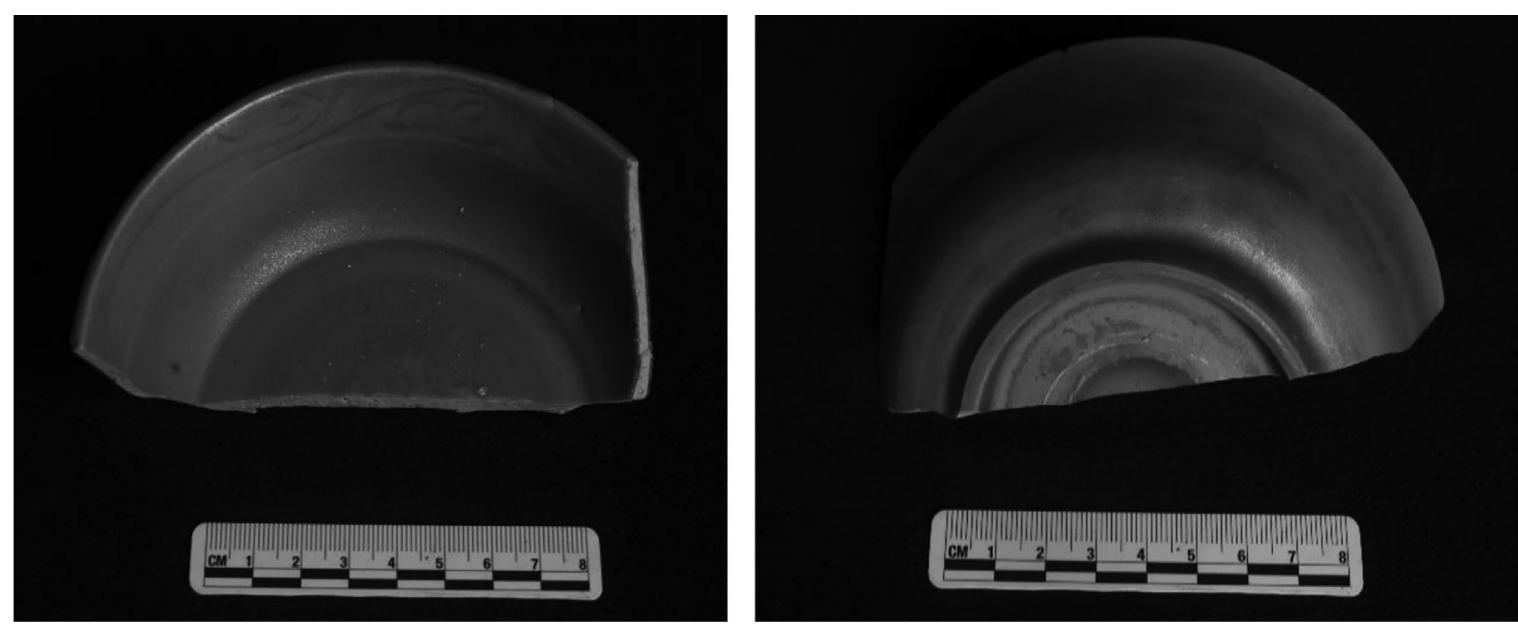

Figure 3: Fragment of celadon bowl (14th CE) with floral motif on interior.

\section{Qingbai Ware}

Another type of ceramic found at the Lamreh site was Qingbai, although there were fewer of these types of fragments found than celadon ware. The results of the morphological analysis showed that these ceramic fragments were divided into the same three types, namely rim sherds, body sherds and base sherds.

The first of these were rim sherds or fragments. They came in several shapes including everted rims, flattened rims, straight rims and flared rims. A thin bluish-white glaze was applied on an off-white fabric. The decorations were plain, with half of them featuring a fine crackled glaze and the other half plain.

The second type was base fragments. These typically consisted of a ring foot base with a trimmed corner on the exterior and with glaze covering the rounded edges of the exterior base (Figure 4). A clear bluish glaze was applied on off-white fabric while the decorations were plain both on the exterior and interior. The third type was body fragments. They mainly had a pale bluish glaze and bluish-white glaze applied on an off-white fabric. A few body fragments featured a fine crackled glaze while the decorations are plain both on the exterior or interior. 
Morphological analysis revealed that the sherds were mostly parts of utensils, such as bowls and dishes of different sizes that were used for daily activities. Generally, the size of Qingbai fragments was five to six centimetres, that number represents the actual size of ceramics. Therefore, a complete form of Qingbai ware at Lamreh site probably have a normal size, for bowls ranging from 11 centimetres to 15 centimetres and plates was around 15 centimetres to 20 centimetres in diameter. Some of the fragments were of great quality and weigh a lot. Relative dating found that these ceramics fragments derived from the 14th century CE at the time of the Southern Song Dynasty and Yuan Dynasty of China.

Historically, the word Qingbai referred to Chinese porcelain ceramics with bluish-white, bluish-blue and bluish-green glaze. Qingbai was also known by the name ching-pai or ceramic ying-qing. Qingbai ceramics are considered to be one of the best-quality porcelain ceramics ever produced by China. These ceramics were first produced in the ninth century CE under the Tang Dynasty and continued to be exported until the following century. However, Qingbai ceramics had their true heyday in the 13th century CE under the Southern Song and Yuan Dynasties (Wood 1999). This had been proven from discoveries of these ceramics in archaeological sites across Southeast Asia, including in Indonesia, Malaysia, Singapore, Thailand, Brunei and the Philippines. They had also been found in Sri Lanka, Saudi Arabia as well as East Africa (Guy 1986). The discovery of Qingbai ceramics around the world served as proof of their former popularity and the vast extend of the value chain (economic networks).

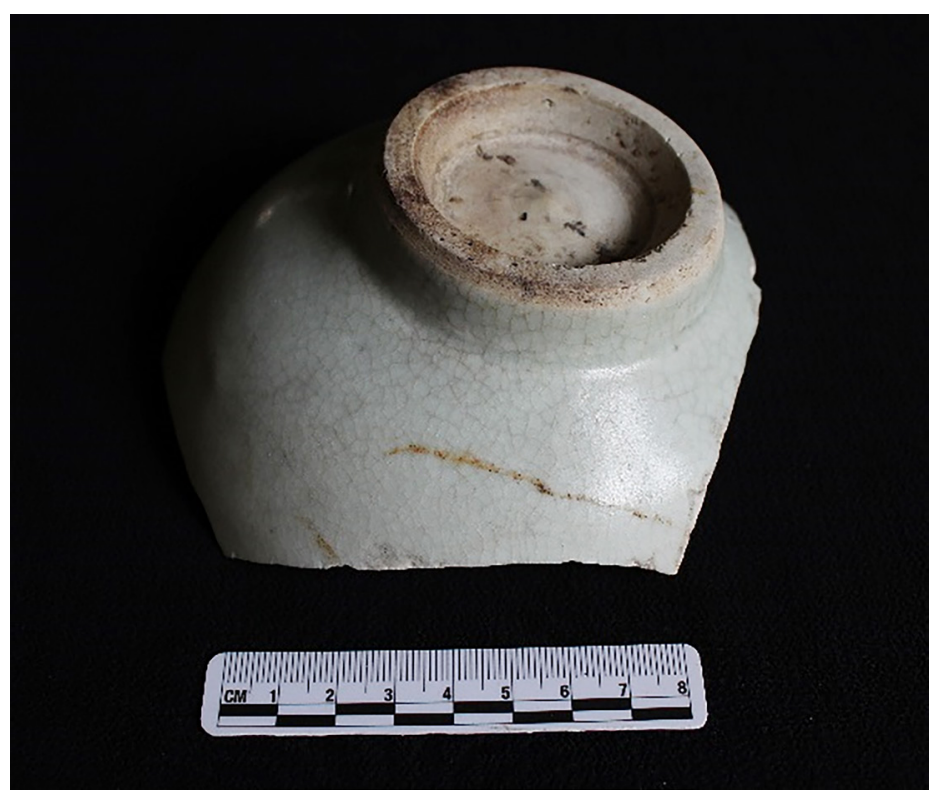

Figure 4: Fragment of Qingbai bowl (14th CE) with trimmed corner on foot rim. 


\section{Blue and White Porcelain}

Another interesting discovery at the Lamreh site were blue and white porcelain ceramic fragments. These are quite rare in many contemporaneous sites, and many where not produced and exported by the Chinese at that time. There was only a small (far less than celadon or Qingbai) but otherwise significant representation at Lamreh. This gives us clues on the value chain and production centres (where they made) and also might be related to rare prestige items. The blue and white porcelain ceramic fragments also consisted of rims, bodies and bases while the fragment diameter ranged from three to eight centimetres. Generally, these rim fragments feature the same type of straight rims and everted rims. The predominant decorations found were geometric motifs on the interior and exterior. Some fragments were made of clean white porcelain stone while others were made of greyish-white stone.

The characteristics of the body fragments were the same as those of the rim fragments, in that some of them were composed of clean white porcelain stone while others were made of greyish-white porcelain stone. The most common decorations on these pieces were floral motifs on the exterior and interior.

As to the base fragments, most of this featured a slim ring foot. One of the significant discoveries was an in-tact ceramic base sherd. On its inside surface were decorative flowers carved into a medallion, while the exterior was adorned with floral motifs. These ceramics were primarily made from greyish-white porcelain stone, giving them a slightly darker look.

Based on the results of the morphological analysis, it was known that the blue and white porcelain ceramic fragments came from utensils such as bowls and plates (Figure 5). Relative dating, meanwhile, revealed that these blue and white porcelain ceramics originated from the 14 th and early 15 th centuries CE. Judging by their quality, the ceramics were believed to have been produced from the Jingdezhen kiln in the early Ming Dynasty. The discovery of 14th century CE blue and white porcelain ceramics at Lamreh reaffirmed Wang Tayuan's recorded statements. In $1349 \mathrm{CE}$ it was written that one of the products traded by China in Lamuri was blue and white porcelain, while the products offered from Lamuri included forest products such as nests, cranes and turtle shells, among others (McKinnon 1988). This means that there is a distinct possibility that the Lamuri region described by Wang Ta-yuan is present-day Lamreh. It also reinforces the fact that the Lamreh site is home to Aceh's most abundant quantity of 14th century CE blue and white porcelain ceramics. Other contemporaneous sites often have a blue and white Yuan ceramics 
representation in their assemblages (e.g., ancient 14th century CE Temasik in Singapore), but the percentage of representation may be higher in Lamreh.

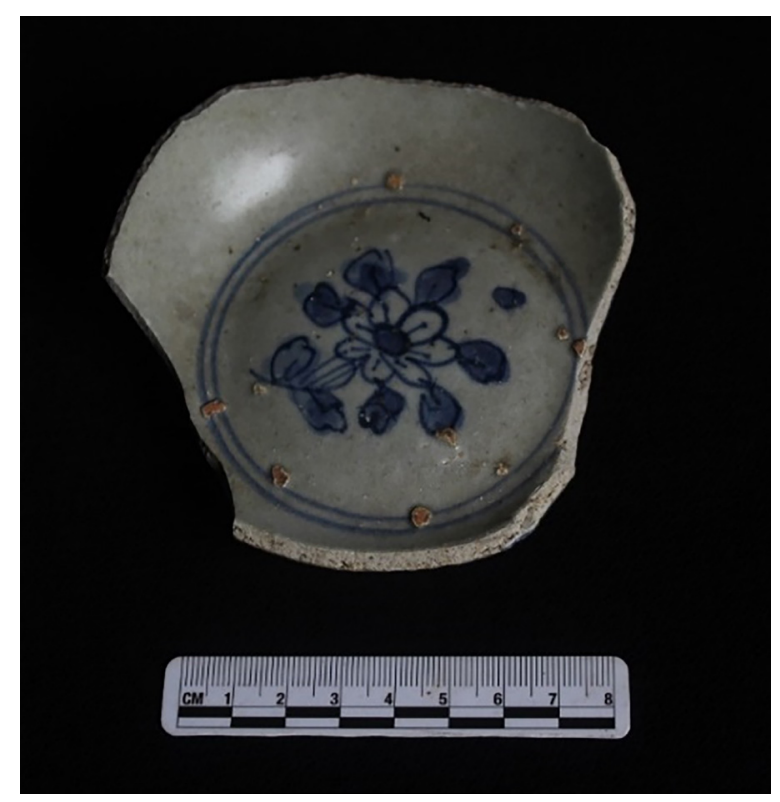

Figure 5: Fragment of blue white porcelain bowl (14th CE) with floral decoration inside medallion.

\section{Coarse Stoneware}

The next most numerous category of sherd material found at the Lamreh site was coarse stoneware. A great variety of types were found, but most of them had light brown slip applied on brown fabric. The fragment types discovered were rolled rims, shoulders with handles, bodies and bases. A familiar decoration was a pressed horizontal lug on the exterior of the shoulder. The common size of these fragments ranged from eight to 15 centimetres. Therefore, it was very difficult to determine the actual size of these wares since the diameter of the fragments was small. However, this characteristic of sherds clearly showed that they were parts of big jars. These jars, or kendi, are associated with the Chinese light brown slip jars produced in Guandong Province of South China during the period of the Yuan and Ming Dynasties (14th to 15th century CE). Generally, these jars were used for water, liquids and possibly for other goods (e.g., grains, spices, fish paste, etc.) on marine voyages. Residue analysis may prove useful to determine the variety of items that may have been stored in this jar. However, they may have been used for multiple purposes at different times as they are sturdy; for example, storing fish at first, then for water on voyages, then for foodstuff at household, possibly large cooking containers for stew, even storing precious items or used for burial goods or burial containers. 


\section{Thai Ware}

Ceramics from Southeast Asian regions were also found at the Lamreh site during the fieldwork. Numerous of such fragments collected consisted of three types. The first was rim sherds of different shapes, but with most of them being everted rims and flattened rims. They featured an off-white slip applied on dark grey fabric. The exterior decorations consisted of brown horizontal lines applied on white slip, while another familiar interior decoration was that of floral design combined with horizontal lines. Some of these fragments had brown horizontal lines on the exterior. The base fragments, meanwhile, were similar to the rim sherds. Familiar decorations on the base sherds included brown floral motifs inside a medallion onto which an off-white slip was applied.

There were also some dishes fragments found with four unglazed identical dots or spur marks on the centre of the base's interior. Interestingly, there were a few pieces of dish fragments with nearly complete forms, where the diameter of the dish was 16 centimetres. This dish was featured with a dark brown fish motif applied on off-white slip on the base's interior (Figure 6). These characteristics clearly show the typical motif of the Sukhothai ware produced in the 15 th century $\mathrm{CE}$.

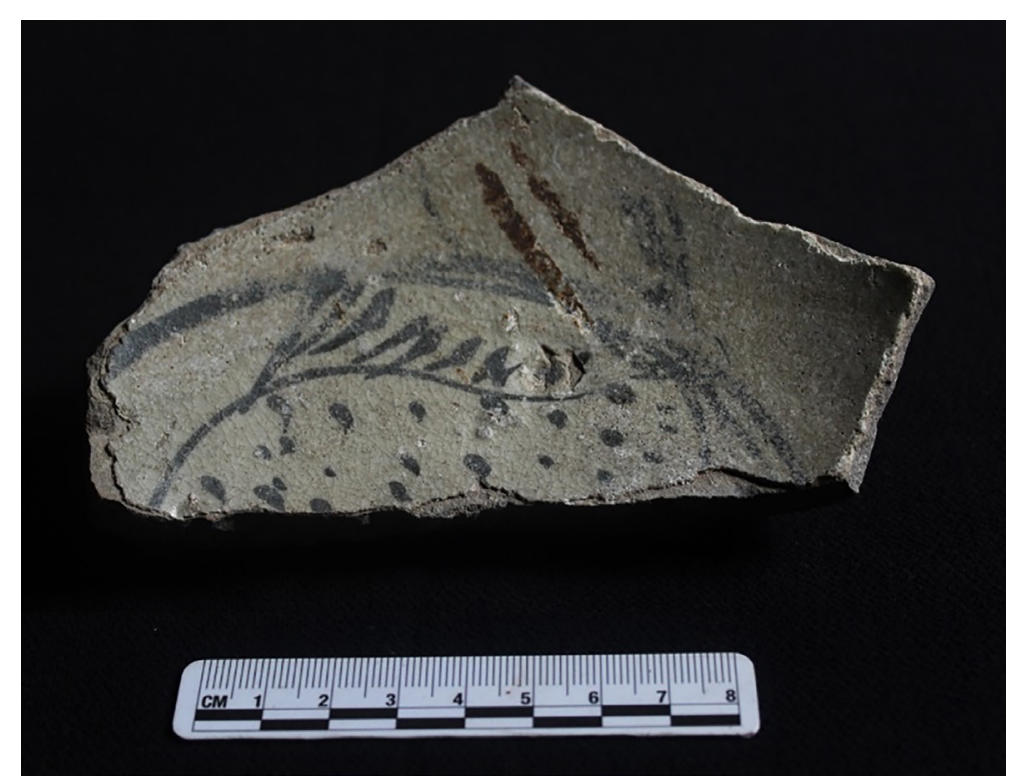

Figure 6: Fragment of Thai dish (15th CE) with brown decoration above white slip.

\section{Burmese Ware}

Fragments of ceramics with blackish-brown slip decorations thought to have originated from Burma (from the Pegu, or present-day Bago region) were also found at the Lamreh site. The size of these fragments was very large, in fact, 
larger than any of the other types of ceramic sherds discovered. These ceramics consisted of yellowish-brown stoneware. Their main characteristic was a layer of blackish-brown slip. The fragments found were rolled rims, shoulders with handles and bases. A few pieces of the body fragments were large sized ranging from 15 centimetres to 20 centimetres and were the largest fragments among other types found on the Lamreh site. Based on reconstruction, it was concluded that these fragments were parts of large jars known as Martavan jars. These are known to be among the largest jars ever produced (Brown 1988). Ceramics researchers believe that these jars were exported from the 1400 s to 1700 s.

\section{Vietnamese Ware}

The history of ceramics production tells us that in addition to China, Vietnam also produced blue and white ceramics. The body of Vietnamese ceramics could be identified by a creamy colour. The production of blue-white ceramics in Vietnam was closely related to the Mongol conquest of China in the 13th century CE (Brown 1988).

Many motifs on Vietnamese ware were adapted from Chinese bluewhite porcelain but they were never the exact duplicates (Brown 1988). Some blue and white ceramic fragments with the above characteristics were found during the survey at the Lamreh site and were believed to be Vietnamese in origin. They comprised of sherds from rims, bodies and bases. The familiar motifs of the Vietnamese ware consisted of floral designs on the interior and exterior. The results of reconstruction demonstrated that most of these sherds came from bowls. These blue and white ceramics were believed to have been exported to Aceh in the 15th century CE during the Lamuri Kingdom period.

It is interesting to note that among the Chinese ceramic fragments, there is also a component of ceramics produced from Southeast Asia, as described in the preceding discussion, especially in the 14th-16th centuries. Nevertheless, there are fewer densities of Southeast Asian stonewares and glazed wares compared to Chinese. Most of the Southeast Asian ceramics at Lamreh originate from the 15th century. Because of policy changes in China, certain types of production and exports were reduced or forbidden during varying periods from the 14th-16th centuries - quite different from the preceding Mongol and Song-Yuan periods. This produced the "Ming Gap" quite evident in both terrestrial and shipwreck sites (Brown 2009; Tai 2011). The restrictions allowed Thai, Vietnamese, Cham and Burmese potting industries to flourish with export trade throughout Southeast Asia. 
The fragments of Southeast Asian ceramics found at the Lamreh site come from Burma, Thailand and Vietnam. There is a possibility that Cham industries (located in central and southern Vietnam) may be represented, but only recently have archaeologists been able to discover the production and distribution extent of the Cham industries. Previously, Cham wares have been classified as belonging to one of the others. Interestingly, no Khmer ceramics are represented but this may have been due to a non-export and non-regionally entrepreneurial culture that may have crystalised during the Angkorian period (Latinis 2017). These countries were successful exporters of ceramics in the maritime trade network in the 15th century CE (Miksic 2009). The evidence at Lamreh and other sites strongly indicate that Aceh was an important market for Southeast Asian ceramic trade (and the contents within the ceramics - ceramics acting as both a commodity itself and container for commodities), especially at a time when there was a shortage of Chinese ceramics in the 15th century-a period better known as the Ming Gap as stated previously.

\section{High-fired Earthenware}

Small quantities of high-fired earthenware fragments were present across the entire surface of the Lamreh site (Figure 7). They were red or orange in colour where the common shape of the fragments was base sherds with carved designs. This pottery fragment was mainly made with clay containing fine sand temper finished with the paddle or anvil technique. The clay containing a high percentage of sand has been identified as the typical clay of Pa-O kiln, southern Thailand. This clay is very suitable for pottery making, especially to produce high-fired earthenware. An impressive quality of Pa-O pottery had various colours ranging from yellowish-white, pinkish-white, yellowish-red, reddishbrown, dark grey and black (Srisuchat 2003). Some of those colours were very similar to the earthenware colour found at Lamreh site. Probably, based on those characteristics, the high-fired earthenware from Lamreh site was $\mathrm{Pa}-\mathrm{O}$ in origin. But, it was very difficult to determine whether the fragment originated from southern Thailand or not due to the absence of spouted neck sherd, the typical shape of Pa-O's pottery. However, hundreds of $\mathrm{Pa}-\mathrm{O}$ fine paste wares, mostly kendis had been found in Java and Intan shipwrecks (Flecker 2003). Other area with sites containing southern Thailand's earthenware included Java Sea, the Philippines, East Java, North Sumatra and in Singapore with dates ranging from ninth to 14th century CE (Srisuchat 2003). The highfired earthenware from these sites was quite similar to the fragments from Lamreh site. Therefore, Lamreh's earthenware fragments closely resembled 
Pa-O wares which were thought to date between 13th and 14th century CE. However, those fragments required further chemical components analysis to provide a better understanding of their dates and origin.
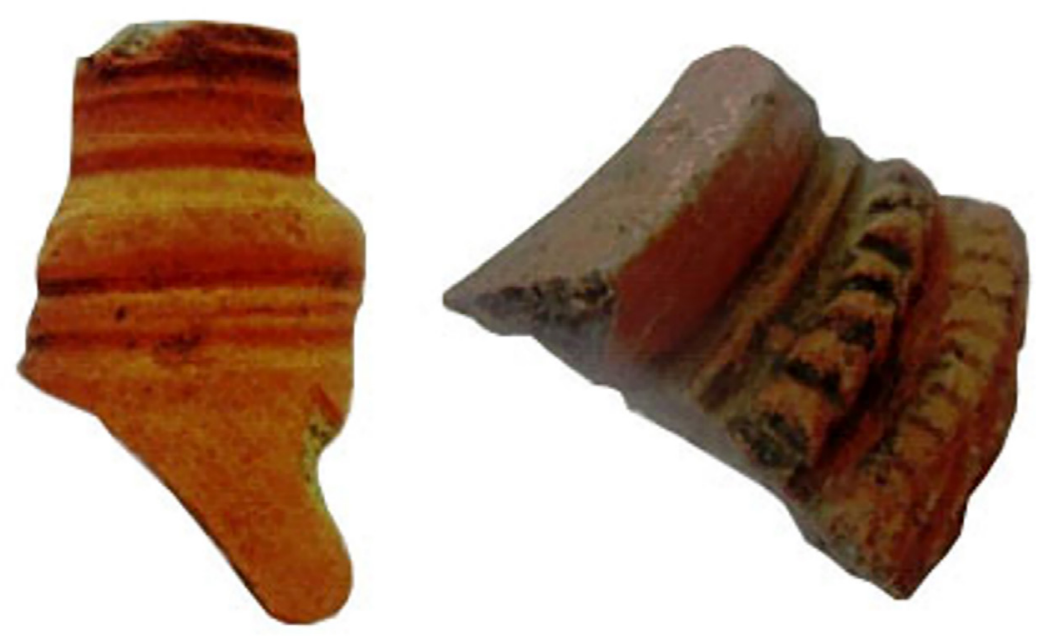

Figure 7: High-fired earthenware (12th-14th CE).

\section{Low-fired Earthenware}

Another important finding was the low-fired earthenware. These fragments were recovered in association with other imported product such as Chinese and Southeast Asian wares. The fragments had different sizes; the smallest size is below two centimetres while the largest size is above ten centimetres in diameter, however, the common size of earthenware fragments ranging from six centimetres to nine centimetres. The distribution of this material at Lamreh site was as important as the other imported products. They were relatively gritty; the fabric consisted of impure clay containing a high percentage of sand. Therefore, the surfaces were coarse on both the interior and exterior. Some of the fragments show incomplete firing which left black smudges on the surface. There were only a few pieces with smooth surfaces. Morphological analysis showed that these types comprised a variety of shapes including jars, cooking pots with plain or two handles on the shoulder, spherical bowl with plain or everted rim, wide-mouth bowls and kendis. These cooking pots were produced by the paddle and anvil technique, and they were frequently undecorated. Among the local people, this shape is commonly known as beulanga or periuk and is commonly used for cooking. Meanwhile, the wide-mouth bowls are very suitable for preparing rice. Presumably, this poorly-fired earthenware was not imported products because they were very different stylistically compared with other imported earthenware. Their date is still unknown; leaving some 
problematic questions. Therefore, scientific analysis is strongly recommended to be carried out on this material to address the issue of their date and origin. Despite that, this type of pottery fragments from Lamreh site might reflect an ancient pottery tradition.

\section{Glassware}

A few fragments of bright blue glass were collected at the Lamreh site during the survey. There were also some dark blue and brown glass fragments discovered. Some of them had horizontal red lines on the exterior (Figure 8). These materials were very similar with the glassware fragments unearthed at Fort Canning, Singapore. Both of them had red stripped lines on the exterior and the colour was dark blue. Based on scientific analysis using energy-dispersive $\mathrm{X}$-ray fluorescence (EDXRF) towards the glassware fragments from Fort Canning, these materials were imported from China in the 14th century CE (Miksic 2013). Similar material was also found at the Java Sea shipwreck and the result of EDXRF analysis had also shown that they came from China as well (Flecker 2003; Miksic 2013). Other similar glass shards had been found in several sites in Sumatra including at Padang Lawas site and Si Pamutung (Perret and Surachman 2016). Therefore, based on these characteristics, the glassware fragments from Lamreh site originated from China exported around 13th or 14th century CE. The appearance of glassware fragments at Lamreh site is quite important even though the number is small. The presence of these materials clearly suggested that that Lamreh was also an important market for Chinese glassware in the Nusantara region and it was an important commodity beside ceramics.

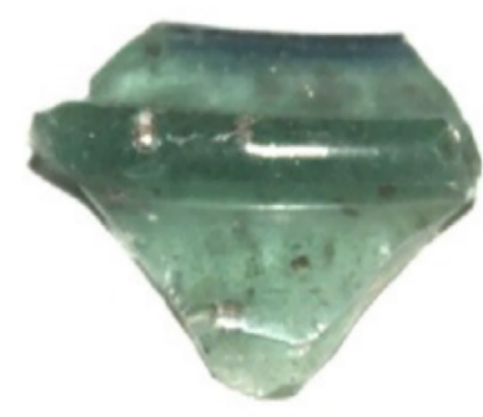

a

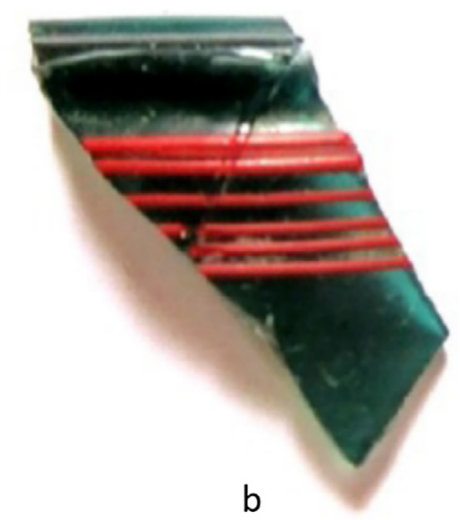

b

Figure 8: Chinese glassware (13th-14th CE) from Lamreh site, showing (a) a blue glassware fragment, and (b) glassware fragment with horizontal red lines motif on exterior. 


\section{Chinese Coins}

Four Chinese bronze coins were found at the Lamreh site. Three of these coins were in fairly good condition so their inscriptions were legible, but one coin had deteriorated so badly that it was impossible to extricate it from its matrix. The three legible coins bore the inscriptions of Yuan Feng Tong Bao, minted between 1078 and 1085; Shao Sheng Tong Bao, minted between 1094 and 1098; and Yuan Fu Tong Bao, minted between 1098 and 1100. These dates were considerably older than those of any of the ceramics or datable artefacts found on the site. It can thus be concluded that the coins must have been brought to Lamreh-Aceh long after their date of manufacture. The same types of coins had been found during excavations at the Fort Canning site in Singapore, confirming the similarities (Miksic 2000). In Java, in the early 14th century CE, Chinese coins replaced locally-minted gold and silver as currency and these coins were also used as the main medium of exchange (Heng 2006). Due to their quantity, the Chinese coins were probably also widely used as currency in Aceh in the 14th century CE (Figure 9).

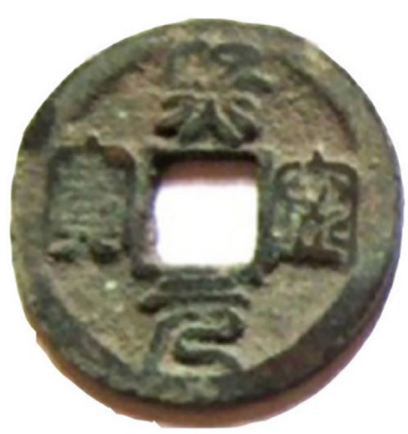

$\mathrm{a}$

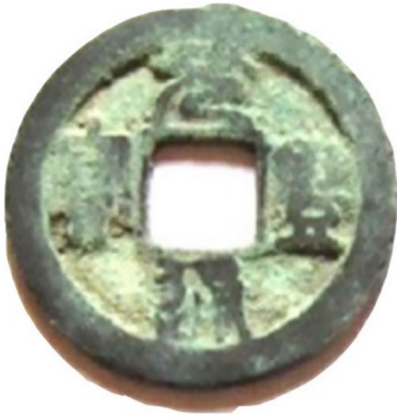

b

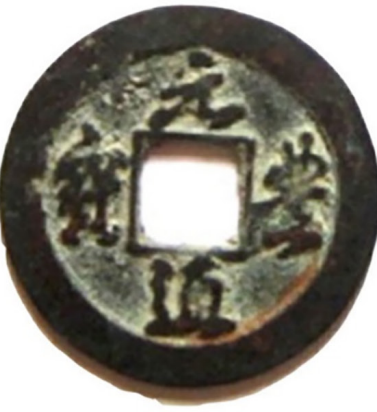

c

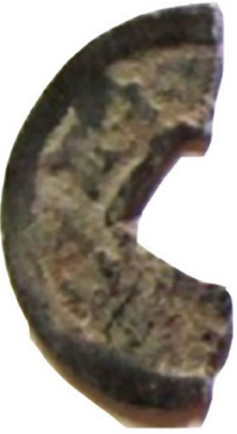

d

Figure 9: Coins of (a) Yuan Feng Tong Bao (1078-1085 CE), (b) Shao Sheng Tong Bao (1094-1097 CE), (c) Yuan Fu Tong Bao (1098-1100 CE), and (d) unknown.

\section{THE ARCHAEOLOGICAL CONTEXT}

The word Lamreh, according to oral tradition, is often linked to the word of Lamuri, Lambri or Ramni, a toponym of an ancient independent region in Aceh. The toponym often appears in foreign accounts from the early ninth until the 15th century CE (McKinnon 1988). However, no writing sources or ancient map are available in context to address the issue. Furthermore, no systematic archaeological excavation in order to provide a stratigraphic layering to examine the culture layers of this site. Previously, limited research 
on Lamreh site showed that this region was a settlement of Lamuri. It became an urban seaport settlement in Aceh during the 13th century CE that had a strong connection across both the South China Sea and Indian Ocean (McKinnon 1988; Feener 2011; Perret 2011).

In the context of Lamuri or other similar toponyms, to this day, the term Lamuri has not been found on tombstones or on other inscriptions at Lamreh site. It is very difficult to determine the association between artefacts and the site. Therefore, we must rely on the archaeological survey results, especially gravestones as in-situ data to address their relationship. However, the presence of the hundreds of gravestones and other artefacts in significant numbers draws up a history of this location. This finding is also a source of data that represents the cultural development of the Acehnese people in the past.

Based on relative dating of the artifacts, most of them were from the 13 th to 15 th centuries CE. During the 13 th century CE, as mentioned in written sources, numerous coastal cities appear to have been largely autonomous under the rule of various coastal rajas (Feener 2011). Samudera Pasai, for example, became an independent region under the rule of a raja as evidenced by many archaeological remains, especially Muslim gravestones scattered in northern Aceh as the centre of the Kingdom (Lombard 1986). Therefore, the findings of plak-pling gravestones and other artifacts at Lamreh site which dated back to the 13th century $\mathrm{CE}$ provided a new perspective on the development of an independent region in Aceh before the 16th century CE.

As described above, the epitaphs on the plak-pling gravestones included several honorific titles carved on the tombstones. The most important of these honour Sultan Muhammad bin Alauddin (15th century CE), Malik Syamsuddin (15th century CE) and Malik Zainal Abidin (15th century CE). Another discovery was Abdurrahim, a personal name without any title inscribed on his gravestone. The title of Sultan is conferred on the person with the highest authority in an Islamic state. The Sultan wields political, military and religious power (Esposito and Sachedina 2004). The word Malik is Arabic for king. However, this position would have been lower than that of the Sultan. The titles inscribed on the gravestones clearly represented a systematic political level of a society in an Islamic independent territory in which the Sultan was the supreme leader.

These discoveries go some way to indicate that Lamreh was an important region from the 13th century $\mathrm{CE}$ in Aceh. Therefore, the characteristic of this region was clearly associated with the Lamuri region, an independent Kingdom in Aceh which was often mentioned by international geographer 
from the ninth until the 15 th centuries CE. The centre of the Kingdom is still unknown, as no sources describe where it was located. With reference to the ancient burial system in the Muslim world, the Sultan's grave was always built adjacent to the palace, and in some cases was even built inside the court. Otherwise, ancient Muslim tombs were always built adjacent to the deceased's residence (Ambary 1998). The finding of the royal gravestone at Lamreh site is not strong enough to build a hypothesis that Lamreh was the centre of the Kingdom. Therefore, systematic archaeological excavation is strongly recommended to address the issue of the centre of the Kingdom.

However, the Kingdom included a large area with relatively stable boundaries as mentioned by Wang Ta-yuan in the 14th century CE. Probably, the centre shifted between locations due to geographical and social factors in Aceh. Another important region of the Lamuri Kingdom that has been identified is Ujong Pancu, a coastal area located 50 kilometres to the south of Lamreh (McKinnon 1988). Nonetheless, the assertion that Lamreh was an important area for the Lamuri Kingdom is proven by the relative dating performed on the plak-pling gravestones which indicated that they date from early 15 th century $\mathrm{CE}$. This makes perfect sense considering that the Lamuri Kingdom still existed in Aceh until the early 16th century CE, as reported at the time by Tomé Pires.

The plak-pling gravestones at the Lamreh site served as a testimony on the Islamisation process in Southeast Asia, with Hindu-Buddhist influences found on the gravestones suggesting that until the 15th century CE Aceh maintained a strong relationship with pre-Islamic culture and religion. In other words, Lamuri was a transitional period spanning pre-Islamic times to the Islamic era. The people of Aceh at that time were yet to fully abandon their use of pre-Islamic symbolism, despite Islam's emergence in Lamuri in late 14th century CE, judging by the Samudera Pasai Sultanate in North Aceh.

Both Marco Polo in the 13th century CE and Cheng Ho in the 15th century $\mathrm{CE}$ conveyed the same message upon visiting the area, describing Lamuri as a region that had embraced Islam (Yule 2018). The plak-pling gravestone period also backs up the records of the two aforementioned explorers. The hundreds of gravestones found at Lamreh bear testament to a flourishing Muslim population in the Lamuri period from the 13th to 15th century CE. The information on the discovered gravestones is unfortunately insufficient to trace the development of the Lamuri Kingdom before the 15th century CE. But, it is possible to do this by analysing the ceramic fragments found at the Lamreh site. The results from the analysis had shown that the percentage among the ceramics types were different. The most common ceramic types was celadon 
ware which accommodated 37 percent of the total ceramics, followed by Qingbai ware (20 percent), low-fired earthenware (19 percent), Chinese blue and white porcelain (12 percent), Thai ware (five percent), Vietnamese ware (three percent), coarse stoneware (two percent) and high-fired earthenware (one percent). All the ceramic fragments recovered from Lamreh came from two main regions, namely China and Southeast Asia. Generally, 71 percent of the identified sherds were Chinese ceramics from the 13th to 14th centuries $\mathrm{CE}$ while 10 percent of the sherds were identified as Southeast Asian ceramics from the 15th century CE. Meanwhile, the other 19 percent of the ceramic sherds were classified as earthenware fragments that could not be identified (Figure 10).

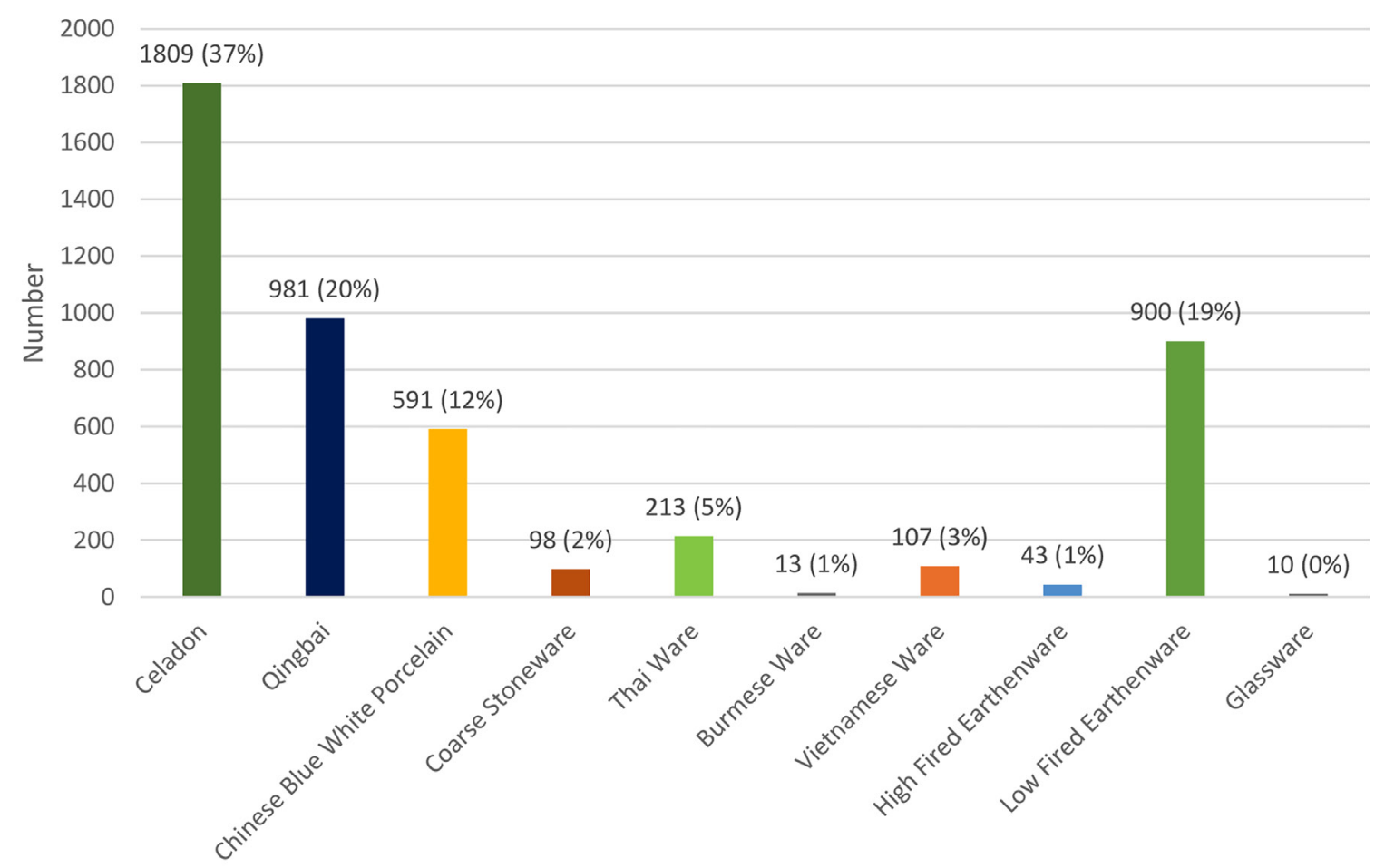

Total number: 4,765

Figure 10: Number of ceramics fragments.

The high proportion of Chinese ceramic sherds from the 14th century CE identified at Lamreh represented a dynamic trace in Aceh in the 14th century CE. This is consistent with Wang Ta-yuan's recorded observation of Lamuri as a busy market with Chinese ceramics as the important commodity traded in Lamuri in 14th century CE. Therefore, the significant amount of ceramic sherds recovered from Lamreh more or less illustrated the prevailing trade in Lamuri during that time. Meanwhile, the absence of Chinese materials from 
the 15th century $\mathrm{CE}$ at Lamreh indicated that trading activities between Aceh and China were disrupted during that century. This was probably due to the introduction of the Ming policy which prohibited trade with the outside world, which is commonly known as the Ming Gap era. This policy obviously had an impact on the trading activities between Aceh and China in the 15th century CE.

However, there were presence of ceramic sherds identified as Southeast Asian materials from the 15 th century CE. Although present in small percentages, this could represent the appearance of other foreign traders in Aceh in the 15th century CE. The absence of Chinese products in the 15th century CE had provided opportunities for other foreign traders to offer their products in Aceh. Southeast Asian ceramics, in this case, were the evidence that represented the important role of Southeast Asian traders in the trading activities at Aceh in the 15 th century CE. Moreover, it seems that they had also replaced the existence of Chinese traders as an influential community in the maritime trade network in the Nusantara Sea during that time. This can be strengthened by the records from Malacca, an important place for Gujarat traders, which noted the absence of Chinese traders in Malacca in the 15th century CE probably due to the Ming policy (Alpers 1976; Cortesão 2017). This made the Gujarat traders as one of the most significant community in Malacca which even made one of the four harbour masters dedicated just to managing their trading activities. In addition, Indian Muslim traders became an important trading community before the economic and political powers of Malacca were captured by the Portuguese in 1511 (Subrahmanyam 2012). Therefore, both Malacca and Lamuri represented the relationship between local and international traders in the maritime trade network along the Straits of Malacca in the 15 th century CE.

Despite that, there were still a few pieces of 15th century CE Chinese celadon found at the Lamreh site. These fragments formed parts of the rim of a bowl. The quality of these pieces is very good, with a shiny olive green glaze. The decoration used is a pattern of lines known as the cash diaper pattern design. It is known that celadon with the cash diaper pattern motif is a typical ceramic from the Longquan kiln produced in the 15th century CE (Wood 1999). This ceramic was not sold globally but instead served as an official gift from the Ming Dynasty to countries that had bilateral relations with China. This ceramic was also known to be a "national gift" to Kingdoms in Southeast Asia. For example, the Khmer Empire with its capital at Angkor was presented with cash diaper pattern ceramics (Brown 2009). 
In the history of the Ming Dynasty (Ming Shi), it is noted that this dynasty sent missions to Lamuri (Nanpoli) under the command of Admiral Cheng Ho four times - in 1408, 1412, 1416 and 1430 (Suryadinata 2005). The cash diaper pattern ceramic fragments from the Lamreh site can be regarded as evidence of Cheng Ho's presence in Lamuri. The dates of Cheng Ho's mission to Lamuri coincide with the age of the plak-pling gravestones at the Lamreh site. Thus, it is quite possible that Cheng Ho visited Lamuri during the reign of Sultan Muhammad bin Alauddin and the cash diaper pattern ceramics were national gifts from the Ming Emperor to the Sultan.

The discovery of gravestones, ceramic and glassware fragments strongly indicated that Lamreh was an important area for the Lamuri Kingdom between the early 13 th to the 15 th centuries CE. It also suggested that Lamreh is one of the oldest settlements along the coastline of Aceh. It was a seaport city and become a global trading centre in Aceh for 300 years. Its heyday overlapped with Samudera Pasai in North Aceh, Kota Cina in North Sumatra, Tumasek in Singapore, Kedah in Peninsula Malaysia and some other areas in Southeast Asia between the 13th and 15th centuries CE.

\section{CONCLUSION}

The Lamreh site is extremely rich in archaeological remains. The survey had found 200 plak-pling gravestones of different sizes and decorations. These plak-pling gravestones carry a strong influence from the pre-Islamic period. The typical motif on the plak-pling from this pre-Islamic period is the tendril motif. Their shape also resembles a menhir or phallus, reflecting a time when Islamic worships had yet to take hold in the region. Meanwhile, the recovery of 15th century CE gravestones belonging to royal officials, such as those of Sultan Muhammad bin Alauddin, Malik Zainal Abidin, Malik Syamsuddin and Abdurrahim at Lamreh represent a systematic political level of society in Islamic independent territory. Therefore, the plak-pling gravestones showed that Lamreh is strongly associated with the Lamuri Kingdom.

Meanwhile, the recovery of ceramic fragments at Lamreh provides an overview of the relationship between the Lamuri Kingdom and international traders (consumption and redistribution). The types of ceramics found originated from two regions, namely China and Southeast Asia. Celadon (14th century CE), Qingbai (14th century CE) as well as blue and white porcelain (14th century CE) are Chinese in origin, while the Southeast Asian ceramics found are Thai (15th century CE), Vietnamese (15th century CE) and Burmese 
(15th century CE) in origin. The ceramics from Lamreh site represent a high trading volume in the Lamuri Kingdom in the 14th century CE, although this decline somewhat in the following century. The decline in trade volume is attributable partially to the Ming Dynasty's policy of closing its relationship and export with the world. This period is often known as the Ming Gap era.

The artifacts show that Lamreh was an important region under Lamuri Kingdom between the early 13 th and 15 th centuries CE. The settlement was to become an urban hub with and intermixture of cultures in Aceh during that time. The gravestones, Chinese ceramics, Southeast Asian ceramics, Chinese coins and glassware illustrate that Lamreh was an important trading centre bridging the South China Sea and the Indian Ocean. These artifacts are also important parts of the evidence of a religious, cultural and commercial relationship between Aceh and the outside world for over 1,000 years.

\section{ACKNOWLEDGEMENTS}

This research is funded by the Universiti Sains Malaysia (USM) through the USM Research Grant 1001/PARKEO/870015. We would like to thank the staff of Centre for Global Archaeological Research (CGAR), USM and the team from Universitas Syiah Kuala Banda Aceh, Indonesia, who supported us to finish this research.

\section{NOTES}

* Amir Husni was born in Aceh on 10 June 1992. Currently, he is completing Masters in the Centre for Global Archaeological Research (CGAR), Universiti Sains Malaysia (USM). His research focuses on ancient maritime trade in Southeast Asian sea. He is an awardee of USM Fellowship.

** Saryulis is a master student of Centre for Global Archaeological Research (CGAR), USM majoring on Islamic archaeology in Southeast Asia.

*** Husaini Ibrahim is a senior lecturer of archaeology in Syiah Kuala University of Banda Aceh. In 2010, he completed PhD at Universiti Sains Malaysia majoring on Islamic archaeology. He has done numerous research works especially on Aceh gravestones and their context with the Islamisation of Southeast Asia.

**** Mokhtar Saidin is the Director of Centre for Global Archaeological Research (CGAR), Universiti Sains Malaysia (USM). He has received numerous international, national and university research grants such as USM Programme Pillar 5: Academic and Student Development - World Class Programme in Pakistan (2014) and Classification of Aceh tombstone in Lamuri site, Aceh, Indonesia. 


\section{REFERENCES}

Adhyatman, S. 1990. Antique ceramics found in Indonesia: Various uses and origins. New York: Ceramic Society of Indonesia.

Alpers, E. A. 1976. Gujarat and the trade of East Africa, c. 1500-1800. The International Journal of African Historical Studies 9 (1): 22-44.

Ambary, H. M. 1998. Menemukan peradaban: Jejak arkeologis dan historis Islam Indonesia. Jakarta: Logos Wacana Ilmu.

Awang, A. (2012). The influences and design evolution in Acehnese tombstone. Journal Online Jaringan Pengajian Seni Bina 53 (1): 53-60.

Brebbia, C. A. and Boquera, A. M. 2016. Islamic heritage architecture and art. London: WIT Press.

Brown, R. M. 1988. The ceramics of South-East Asia: Their dating and identification. Oxford: Oxford University Press.

Brown, R. M. 2009. The Ming gap and shipwreck ceramics in Southeast Asia: Towards a chronology of Thai trade ware. Bangkok: Siam Society.

Chaudhuri, K. N. 1985. Trade and civilisation in the Indian Ocean: An economic history from the rise of Islam to 1750. Cambridge: Cambridge University Press.

Chuan, G. K. and Cleary, M. 2005. Environment and development in the Straits of Malacca. London: Routledge.

Cortesão, A. 2017. The suma oriental of Tomé Pires: An account of the east, from the Red Sea to Japan, written in Malacca and India in 1512-1515, vol. 2. New York: Routledge.

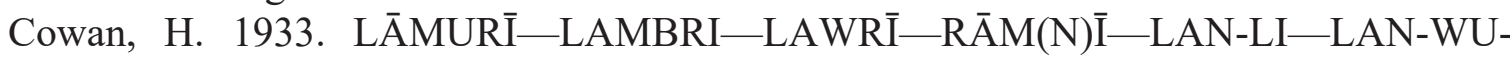
LI-NAN-PO-LI. Bijdragen tot de Taal-, Land-en Volkenkunde van NederlandschIndië 1 (90): 421-424.

Esposito, J. L. and Sachedina, A. A. 2004. The Islamic world: Past and present. Oxford: Oxford University Press.

Feener, R. M. 2011. The Acehnese past and its present state of study. Leiden: KITLV Press.

Flecker, M. 2003. The thirteenth-century Java Sea Wreck: A Chinese cargo in an Indonesian ship. The Marinerr's Mirror 89 (4): 388-404.

Gipouloux, F. 2011. The Asian Mediterranean: Port cities and trading networks in China, Japan and South Asia, 13th-21st century. Cheltenham: Edward Elgar Publishing.

Guy, J. 1986. Oriental trade ceramics in South-East Asia, ninth to sixteenth centuries: With a catalogue of Chinese, Vietnamese and Thai wares in Australian collections. Oxford: Oxford University Press.

Hall, K. R. 2010. A history of early Southeast Asia: Maritime trade and societal development, 100-1500. London: Rowman \& Littlefield Publishers.

Harrisson, T. 1959. Export wares found in West Borneo. Oriental Art 2 (5): 42-53.

Heng, D. T. S. 2006. Export commodity and regional currency: The role of Chinese copper coins in the Melaka straits, tenth to fourteenth centuries. Journal of Southeast Asian Studies 37 (2): 179-203.

Latinis, D. K. 2017. Ceramic industries, value chains, and economic models: Competing with the Khmer. Paper presented at the Binh Dinh Ancient Ceramics: Vijaya Kingdom and Its Relationship with Thang Long Citadel-Dai Viet (11th-15th centuries), Quy Nhon city, Vietnam. 
Lombard, D. 1986. Kerajaan Aceh: Jaman Sultan Iskandar Muda, 1607-1636. Jakarta: Balai Pustaka.

McKinnon, E. 1977. Research at Kota Cina, a Sung-Yüan period trading site in east Sumatra. Archipel 14 (1): 19-32.

1984. Kota Cina: Its context and meaning in the trade of Southeast Asia in the twelfth to fourteenth centuries. PhD diss., Cornell University, New York.

1988. Beyond Serandib: A note on Lambri at the northern tip of Aceh. Indonesia 1 (46): 103-121.

Meri, J. 2005. Medieval Islamic civilization: An encyclopedia. New York: Taylor \& Francis. 2018. Routledge revivals: Medieval Islamic civilization (2006), an encyclopedia. New York: Taylor \& Francis.

Miksic, J. N. 2000. Recent archaeological excavations in Singapore: A comparison of three fourteenth-century sites. Bulletin of the Indo-Pacific Prehistory Association 20 (5): $1-6$.

2009. Southeast Asian ceramics: New light on old pottery. Singapore: Southeast Asian Ceramic Society.

2013. Singapore and the Silk Road of the Sea, 1300-1800. Singapore: NUS Press.

Montana, S. 1997. Nouvelles données sur les royaumes de Lamuri et Barat. Archipel 53 (1): 85-95.

Perret, D. 2011. Aceh as a field for ancient history studies. Leiden: KITLV Press.

Perret, D., Razak, K. B. A. and Kalus, L. 1999. Batu Aceh: Warisan sejarah Johor. Johor Baharu: Yayasan Warisan Johor.

Perret, D. and Surachman, H. 2015. Barus negeri kamper: Sejarah abad ke-12 hingga pertengahan abad ke-17. Jakarta: Kepustakaan Populer Gramedia.

Perret, D. and Surachman, H. 2016. History of Padang Lawas North Sumatra: The site of Si Pamutung. Asian Review of World Histories 4 (1): 165-168.

Reid, A. 1995. Witnesses to Sumatra: A traveller's anthology. New York: Oxford University Press.

Risso, P. A. 2018. Merchants and faith:Muslim commerce and culture in the Indian Ocean. New York: Routledge.

Sen, T. T. 2009. Cheng Ho and Islam in Southeast Asia. Singapore: Institute of Southeast Asian Studies.

Srisuchat, A. 2003. Earthenware from archaeological sites in southern Thailand: The first century BC to the twelfth century AD. In Earthenware in Southeast Asia, ed. Miksic, J. N., 249-260. Singapore: Singapore University Press.

Subrahmanyam, S. 2012. The Portuguese empire in Asia, 1500-1700: A political and economic history. London: John Wiley \& Sons.

Suryadinata, L. 2005. Admiral Zheng He and Southeast Asia. Singapore: International Zheng He Society.

Tai, Y. S. 2011. Ming gap and the revival of commercial production of blue and white porcelain. China Bulletin of the Indo-Pacific Prehistory Association, 31.

Tibbetts, G. R. 2002. A study of the Arabic texts containing material on South-East Asia. London: Taylor \& Francis.

Valenstein, S. G. 1988. A handbook of Chinese ceramics. New York: Metropolitan Museum of Art. 
Wheatley, P. 1959. Geographical notes on some commodities involved in Sung maritime trade. Journal of the Malayan Branch of the Royal Asiatic Society 32 (2): 3-140.

Wolters, O. W. 1967. Early Indonesian commerce. New York: Cornell University Press.

Wood, N. 1999. Chinese glazes: Their origins, chemistry, and recreation. Pennsylvania: University of Pennsylvania Press.

Yule, H. 2018. The travels of Marco Polo, vol. 2. Frankfurt: Salzwasser-Verlag. 